[Pre-edited version of article Ferreira, Nuno (2017) Working children in England and Wales: waking up from inertia. King's Law Journal, 28 (3). pp. 381-402. ISSN 0961-5768]

\title{
WORKING CHILDREN IN ENGLAND AND WALES: WAKING UP FROM
}

INERTIA

\author{
Nuno Ferreira*
}

\begin{abstract}
:
Child work in England and Wales has been a well-researched topic from a historical perspective, but increasingly side-lined in socio-legal scholarship. This work aims to bring back this topic to the legal debate, by considering the relevant legal framework and related international and EU instruments, the experiences of working children in England and Wales, and the legal enforcement of the current standards by public authorities. Priorities for the future are also highlighted, with the ultimate intention of prompting greater monitoring and empirical research in this field.
\end{abstract}

Key words: children's rights, child labour, child work, European Union, labour law, Young Workers Directive, childhood

\section{WORKING CHILDREN IN ENGLAND AND WALES: PAST AND PRESENT}

One may say that child work goes back to the beginning of history. ${ }^{1}$ Although there are no reliable records, it is safe to believe that children did assist, to the extent of their capacities, in gathering food, finding shelter and ensuring the safety of their families and communities since times immemorial. Yet, in the English and Welsh context, ${ }^{2}$ the history of child labour is often only highlighted since the beginning of the Industrial Revolution. It appears that only with the advent of the Industrial Revolution the involvement of children in the world of labour became problematic or, at any rate, debated and contentious.

\footnotetext{
* Professor of Law, University of Sussex, UK. I wish to express my gratitude to Dr Maria Moscati, Dr Amir PazFuchs, Professor Keith Ewing and the anonymous reviewers for their constructive and challenging comments and suggestions.

1 The expression 'child work' will be used throughout this article to refer to any form of work carried out by children, without implying any judgement on its appropriateness or legality. The expression 'child labour', instead, will only be used when the type of child work in question can be deemed inappropriate or unlawful under the applicable legal framework. See, also, N. Ferreira, 'Working Children in Europe: A Socio-Legal Approach to the Regulation of Child Work', European Journal of Comparative Law and Governance (2017) 4, 43-104, 50.

2 This article deals in particular with the English and Welsh context, but where relevant available data refers to a different geographical delimitation within the United Kingdom, express reference will be made to that precise geographical scope.
} 
Indeed, children's work in factories was gradually questioned and became object of criticism. ${ }^{3}$ Child work at that time - as still nowadays - was admittedly a complex phenomenon resulting from the 'triangle drawn up by the production process, the household or family, and the regulation imposed by the state. ${ }^{4}$ That complexity was compounded by the fact that children could be found in a range of labour contexts beyond factories, including farms, mines, workshops and armed forces. ${ }^{5}$ Several factors contributed to the slow moral and legal condemnation of child labour in the nineteenth century, including a change of paradigm of childhood, increasing men's wages and gender equality, and increasing regulation of vulnerable workers and working time. ${ }^{6}$

The legislative initiatives since early nineteenth century to try to limit child labour in England and Wales, particularly in the shape of a series of Factory Acts, ${ }^{7}$ were strongly opposed by manufacturers, factory owners and key conservative and liberal thinkers. These defended pro-child-employment policies on the basis of the lightness of the work carried out by children, the need to protect the market from state intervention, and the harm that legislative intervention could cause to the competitiveness of British production. ${ }^{8}$ Nevertheless, several Factory Acts did become law and regulated child work, with the positive outcome of slowly eliminating the worst cases of child labour. Although during the Second World War even young children were called upon to contribute with their work, ${ }^{9}$ that seemed to constitute for the most part an exception. England and Wales - and more generally all European Union (EU) countries - thus progressively developed a strong protective legal framework for child workers, restricting to a great extent their involvement with the labour market.

The current legal framework applicable to child work in England and Wales is scattered throughout a range of statutes that can only be described as fairly outdated and fragmented. These include the Merchant Shipping Act 1995, the Management of Health and Safety at Work

\footnotetext{
3 J. Humphries, Childhood and Child Labour in the British Industrial Revolution (Cambridge: Cambridge University Press, 2010).

${ }^{4}$ P. Bolin-Hort, Work, Family and the State: Child Labour and the Organization of Production in the British Cotton Industry, 1780-1920 (Lund: Lund University Press, 1989) at 16.

${ }^{5}$ Humphries, Childhood and Child Labour in the British Industrial Revolution.

${ }^{6}$ Ibid.

${ }^{7}$ Hobbs, McKechnie, and Lavalette, Child Labour: A World History Companion at 85 ff; M. Bourdillon et al., Rights and Wrongs of Children's Work (New Brunswick, New Jersey: Rutgers University Press, 2010) at $40 \mathrm{ff}$; S. Hobbs and J. McKechnie, Child Employment in Britain: A Social and Psychological Analysis (Edinburgh: The Stationery Office: Scotland, 1997) at $14 \mathrm{ff.}$

${ }^{8}$ S. Hobbs, J. McKechnie, and M. Lavalette, Child Labour: A World History Companion (Oxford: ABC-CLIO, 1999) at 195 ff; M. Lavalette, Child Employment in the Capitalist Labour Market (Aldershot: Avebury, 1994) at 223.

${ }^{9}$ B. Mayall and V. Morrow, You Can Help Your Country: English Children's Work During the Second World War (London: Institute of Education Press, 2011).
} 
Regulations 1999, the Children (Performances) Regulations 1968, the Children and Young Persons Act 1963, and the Children and Young Persons Act 1933. It is Part II of this latter statute that establishes the most relevant provisions in this field: it protects school attendance, limits work to 2 hours/day and 12 hours/week during school term and 2 hours on Sundays, it prohibits night work between 7pm and 7am, and it allows light work (defined as work that is not likely to be harmful to the safety, health or development of children, and is not such as to be harmful to their attendance at school or to their participation in work experience) from the age of 13, if allowed by bylaws. ${ }^{10}$ This statute also sets 14 as minimum age of employment, but 16 is the school leaving age in England and Wales, ${ }^{11}$ effectively postponing the employment age until 16. ${ }^{12}$ The Children and Young Persons Act 1933 also affords local authorities powers to enforce these norms and impose more restrictive conditions and requirements. Similarly, it falls on local authorities to issue work permits for children under the age of 13 taking part in public performances, and for children between the ages of 13 and 16 carrying out light work. ${ }^{13}$ The Management of Health and Safety at Work Regulations 1999 are also crucial in establishing high standards in the quality of the information provided to child workers and their parents (s. 10) and in the reduction of risks in the work environment in which children carry out their activities (s. 19).

Yet, child labour appears to persist in England and Wales: for example, at a seminar organised by the European Children's Rights Unit of the University of Liverpool in 2015, several children of high school age reported on highly suspicious and most likely illegal practices they experienced in the work place, including in relation to low pay, harm to education, informal work arrangements, deficient health and safety conditions, and sexist recruitment procedures. ${ }^{14}$ Whilst some suggest that children would benefit from more relaxed

\footnotetext{
${ }^{10}$ Confirmed by governmental guidance: Department for Children, Schools and Families, Guidance on the Employment of Children, <https://www.gov.uk/government/uploads/system/uploads/attachment_data/file/193326/Child_employment09.p df $>$, accessed 1 September 2017 at 5.

${ }^{11}$ Department for Education, School attendance Guidance for maintained schools, academies, independent schools and local authorities, <https://www.gov.uk/government/uploads/system/uploads/attachment_data/file/564599/school_attendance.pdf> , accessed 1 September 2017.

${ }^{12}$ It is worth noting that the current legal framework is far from clear and straightforward, and both child workers and employers would benefit from greater clarity and certainty.

${ }^{13}$ UK Government, Child work permit (England and Wales)', <https://www.gov.uk/child-work-permit-englandwales>, accessed 1 September 2017.

${ }^{14}$ Seminar 'Children as Workers: Empowered or Exploited?', European Children’s Rights Unit, University of Liverpool, 7 July 2015, <https://www.liverpool.ac.uk/law/research/european-childrens-rightsunit/projects/seminar-six/>, accessed 1 September 2017.
} 
work regulations, ${ }^{15}$ others - such as ex-Children's Commissioner for England Maggie Atkinson - are adamant that working on top of a demanding educational workload could be the 'last straw' for some youngsters. ${ }^{16}$ There are good reasons to believe that Lavalette's assessment of child work in England and Wales in the 1990s remains as valid then as now: 'child labour is a structural phenomenon of modern societies that takes its present form due to the interaction of economic, political and ideological factors' with historical roots, turning child labour into an activity that is far closer to 'a particular form of labour exploitation in modern capitalist societies' rather than a 'harmless “socialising” activity' ${ }^{17}$ The Council of Europe's Commissioner for Human Rights, Nils Muižnieks, has also highlighted reports of children working long hours in the UK. ${ }^{18}$ The same can be observed in other Western, 'developed' countries such as Australia, where instances of exploitation of workers as young as 13 have been reported to take place in the shape of underpayment and payment in kind. ${ }^{19}$

Despite this state of affairs, for more than a decade child work in England and Wales has been worryingly off the radar of social and legal scholars, the third sector and policy makers alike. Indeed, in the 1990s and early 2000s, the theme of child work was recurrently discussed by scholars and policy makers, perhaps prompted mainly by EU-wide initiatives and debates (see section IV). Once that momentum was lost, one can witness a worrying dearth of academic exploration and public interest in this theme, even though nothing suggests that child work has disappeared or become fully unproblematic in England and Wales.

This article brings this important matter back to the agenda by exploring the current English and Welsh legal framework, its compliance with international and European standards, the experiences of child workers in England and Wales, and the way the existing legal framework is implemented. The regulation of child work is clearly not a priority for UK labour policy makers: as the 2016 Employment Opportunities for Young People Inquiry suggested, the focus currently lies on integrating young people into the labour market, ${ }^{20}$ with very little

\footnotetext{
15 Fran Abrams, What's Wrong with Child Labour?, BBC Radio 4, <http://www.bbc.co.uk/programmes/b00tt575>, accessed 1 September 2017.

16 Maggie Atkinson quoted in Fran Abrams, Should children be expected to work, BBC, 2010, <http://www.bbc.co.uk/news/magazine-11351057>, accessed 1 September 2017.

${ }^{17}$ Lavalette, Child Employment in the Capitalist Labour Market at 3.

${ }^{18}$ N. Muižnieks, 'Child Labour in Europe: A Persisting Challenge', <http://www.coe.int/en/web/commissioner//child-labour-in-europe-a-persisting-challen-1>, accessed 1 September 2017.

${ }^{19}$ ABC News, 'Melbourne Restaurant Owner Fined for Paying Wages in Pizza and Soft Drink', ABC News, 10 June 2014, <http://www.abc.net.au/news/2014-06-10/restaurant-owner-fined-for-paying-wages-in-pizzas-andsoft-drink/5511542>, accessed 1 September 2017.

20 Work and Pensions Committee, 'Employment Opportunities for Young People Inquiry', $<$ http://www.parliament.uk/business/committees/committees-a-z/commons-select/work-and-pensionscommittee/inquiries/parliament-2015/young-people-employment-16-17/>, accessed 1 September 2017.
} 
attention specifically paid to their working conditions and irregular practices affecting them. Moreover, labour market authorities only seem to feel concerned about children's working conditions in the context of modern slavery, forced labour and trafficking, ${ }^{21}$ thus leaving unscrutinised a broad range of unlawful and harmful work situations in which children may find themselves. Furthermore, as it will become clear throughout this article, in practice child labour tends to be seen as a foreign policy matter, raising no concerns and requiring no particular monitoring in the domestic context.

After more than a decade of academic and policy-making silence in relation to child work, this article fundamentally shifts that focus and returns the discussion to other essential matters surrounding the experiences of child workers in England and Wales, such as the impact of work on children's well-being and their educational attainment. The final aim is to ensure that children entering the labour market in England and Wales benefit from meaningful work experiences, that can constitute an advantage to their personal and professional development, rather than impair it. As I have argued elsewhere, it is entirely justifiable to retain and enhance a policy framework thoroughly regulating children's access to and conditions in the labour market, on grounds related to children's rights and wellbeing, as well as a range of legal, social, economic and cultural factors. ${ }^{22}$ This position will frame the analysis below.

Both the English and Welsh and EU legal frameworks applicable to child work need to comply with the International Labour Organization (ILO) and United Nations (UN) relevant instruments. It is thus pertinent to start by looking in turn more closely at the ILO and UN legal frameworks on child labour (section II). Then the EU legal and policy framework will be analysed (section III), to subsequently allow us to situate the English and Welsh current setup within the context of global and regional obligations. Focus will then be placed on the modern experiences of working children in England and Wales (section IV), to understand the appropriateness of the existing norms and practices. In the light of the legal and policy frameworks analysed and the real lived experiences of child workers, attention will then shift to the operationalisation and enforcement of the English and Welsh child work policy (section V). Finally, the conclusion will draw some key messages and highlight policy recommendations (section VI), in particular call for the strengthening of public-led enforcement of child labour regulations and the carrying out of extensive longitudinal empirical research into work experiences of children in England and Wales.

\footnotetext{
${ }^{21}$ Further on this point, see discussion in section V.

${ }^{22}$ For a lengthier discussion of the justification for the current protective legal frameworks on child work, see Ferreira, 'Working Children in Europe: A Socio-Legal Approach to the Regulation of Child Work'.
} 


\section{ILO AND UN SETTING THE BASIC STANDARDS}

The ILO, as the UN agency that regulates labour standards, is the most obvious global source of labour standards and has been at the forefront of the fight against child labour around the world for several decades. This fight has taken the shape of two particular instruments: Conventions No. 138 concerning Minimum Age for Admission to Employment (C138), adopted in 1973, and No. 182 concerning the Prohibition and Immediate Action for the Elimination of the Worst Forms of Child Labour (C182), adopted in 1999. ILO’s fight against child labour is operationalised by its International Programme on the Elimination of Child Labour (IPEC), created in 1992.

As its name indicates, ILO C138 established a minimum age to be admitted to work, set at no lower than the age of completion of compulsory schooling and, in any case, no lower than 15 (Article 2(3)). More generally, Article 1 establishes that children should be guaranteed their 'fullest physical and mental development'. Simultaneously, ILO C138 set out a framework to progressively eliminate child labour (understood as unlawful child work). The subsequent ILO C182 has placed the spotlight on the worst forms of child labour, in particular - as its Article 3 explains - slavery, pornography, illicit activities and (other) work harmful to children's health, safety or morals. The UK has ratified both these ILO instruments, and specified 16 years old as minimum age of employment or work in the context of ILO C $138 .^{23}$

Despite being sometimes criticised - amongst other reasons - for restricting children's autonomy and for not being sufficiently tailored to local, culturally-specific conditions around the globe, ${ }^{24}$ ILO C138 and C182 have been consistently retained as fundamental standards by the ILO, as well as recurrently endorsed by the UN Committee on the Rights of the Child (UNCRC). ${ }^{25}$ This should be all the more the case in the European Union context, as I have argued elsewhere, especially considering that all EU countries can be held to be economically developed and can thus afford offering better socio-economic conditions to children. ${ }^{26}$ The UK, in particular, is consistently placed amongst the highest places in development ranking tables

\footnotetext{
${ }^{23}$ International Labour Organization (ILO), 'Ratifications of C138 - Minimum Age Convention, 1973 (No. 138)', <http://ilo.org/dyn/normlex/en/f?p=1000:11300:0::NO:11300:P11300_INSTRUMENT_ID:312283>, accessed 1 September 2017.

${ }^{24}$ For an overview of this debate, see N. Ferreira, 'Working Children in Europe: A Socio-Legal Approach to the Regulation of Child Work', $53 \mathrm{ff}$.

${ }^{25}$ See, for example, UN Committee on the Rights of the Child (CRC) (2013). General Comment No. 17 On the right of the child to rest, leisure, play, recreational activities, cultural life and the arts (art. 31). UN Doc. CRC/C/GC/17.

${ }^{26}$ Ferreira, 'Working Children in Europe: A Socio-Legal Approach to the Regulation of Child Work'.
} 
- for example, the UK ranks $16^{\text {th }}$ in the UN Human Development Index (HDI), which considers, amongst other factors, both education and income. ${ }^{27}$

The ILO standards contained in these instruments have been considered by the EU when it negotiated and approved Directive 94/33/EC of 22 June 1994 on the protection of young people at work, generally referred to as Young Workers Directive (YWD) (see section III), but the YWD could have complied more effectively with ILO C138 and C182. ${ }^{28}$ This seems to be the case particularly in relation to: 1) work entailing specific risks and carried out by adolescents (Article 7(3) YWD falling slightly short of the ILO norm), 2) the terminology adopted (the ILO adopting the more CRC-compatible notion of 'child', rather than drawing distinctions between children of different ages), 3) the absence of criminal sanctions in the YWD (although these are encouraged by the ILO), and 4) the scope of application of the YWD (the ILO instruments applying to both employment and work, whilst the YWD applies only to work within the context of legally recognised employment contracts or relationships). This is all the more important in the context of the current Brexit negotiation, as (depending on the outcome of the negotiation process) the EU will most likely cease to be the most significant international actor influencing UK domestic legal standards in this field. That being the case, the ILO has the potential to re-acquire significance in this regulatory space, and develop some leverage on UK labour law. The English and Welsh policy makers in this field should thus look beyond the standards set in the YWD and how it has been transposed into UK law; they should carefully consider how to comply with ILO standards, and also exceed those minimum benchmarks to the extent allowed by socio-economic resources available.

It is also worth looking beyond the remit of the ILO, as other documents and work carried out in the context of the UN are relevant in terms of the regulation of child labour and child workers. The UN 1989 Convention on the Rights of the Child (CRC) contributed to this debate by establishing in its Article 32 'the right of the child to be protected from economic exploitation and from performing any work that is likely to be hazardous or to interfere with the child's education, or to be harmful to the child's health or physical, mental, spiritual, moral or social development'. This follows the norm contained in Article 10(3) of the 1966 International Covenant on Economic, Social and Cultural Rights (ICESCR). Article 32 CRC

\footnotetext{
${ }^{27}$ United Nations Development Programme, 'Human Development Report 2016: Human Development for Everyone', (New York: United Nations Development Programme, 2016) $<$ http://hdr.undp.org/sites/default/files/2016_human_development_report.pdf $>$, accessed 1 September 2017, at 202.

${ }^{28}$ Nuno Ferreira, 'Child Labour and EU Law and Policy: A Regional Solution for a Global Issue', in Helen Stalford and Ingi Iusmen (eds.), The EU and the Global Protection of Children's Rights: Norms, Laws and Policy Dimensions (Opladen/Berlin/Toronto: Barbara Budrich, 2016), 259-88.
} 
is complemented by other norms in the CRC that affect children working in specific contexts, including Articles 11 and 35 on trafficking, 19 on abuse and neglect, and 34 on sexual exploitation.

Similarly to what we have seen above with regard to the relationship between the ILO instruments and the YWD, confronting the YWD with the CRC highlights a few shortcomings in the YWD. ${ }^{29}$ Besides the already mentioned lack of use of the terminology 'child' in a consistent manner throughout the YWD, the CRC - in particular its Article 32(2) - would have also required the explicit inclusion in the YWD of legislative, administrative, social and educational enforcement measures, including 'appropriate penalties or other sanctions' (as opposed to mere 'measures' under Article 14 YWD). This holistic approach to enforcement of child labour regulations should also be acted upon by UK authorities - something far from the current reality, as it will be seen below (section V).

The UNCRC has also actively addressed in one of its General Comments the issue of child labour, by alerting - in the context of the impact of businesses on children's rights - to the potentially 'life-long, irreversible and even trans-generational consequences' of child labour, amongst other interconnections between business and children. ${ }^{30}$ The Committee on Economic, Social and Cultural Rights leant its support to the UNCRC position by taking note of it in its own General Comments. ${ }^{31}$

In the light of this international framework, and the tensions identified between that framework and the YWD, it is now essential to look further into the current EU framework applicable to child work.

\section{THE EUROPEAN UNION CONTEXT: INFLUENCES AND RESISTANCE}

The YWD requires EU Member States to protect children from economic exploitation and any work that may have a negative impact on their development or education (Article 1(3)). The YWD determines that the minimum age of admission to employment cannot be lower than 15 , and aligns this minimum age with the milestones of the educational system (Article 1(1)). The YWD also limits a child's overall working time to 40 hours/week and 8 hours/day, and bans

\footnotetext{
${ }^{29}$ Ferreira, 'Child Labour and EU Law and Policy: A Regional Solution for a Global Issue'.

${ }^{30}$ Committee on the Rights of The Child, General Comment No. 16 (2013) on State Obligations Regarding the Impact of Business on Children's Rights, CRC/C/GC/16, 2013, at par. 4.

${ }^{31}$ Committee on Economic, Social and Cultural Rights, General Comment No. 24 on State Obligations under the International Covenant on Economic, Social and Cultural Rights in the Context of Business Activities, E/C.12/GC/24, 2017.
} 
child night work (Articles 8 and 9). According to the YWD, children may take part in combined work/training schemes from the age of 14 onwards and may carry out light work from the age of 13 onwards (up to 12 hours/term-time / week and 2 hours/school / day, to ensure enough leisure and school homework time) (Articles 4 and 8). Children can also be involved in cultural or similar activities as long as, amongst other requirements, the activities in question are not likely to be harmful to the child's safety, health, development or education (Article 5). Finally, the YWD imposes on employers several obligations in relation to child workers in the light of their vulnerability (Articles 6 and 7). ${ }^{32}$

The deadline for transposing the YWD into Member States' domestic legal systems was 22 June 1996, but the UK government successfully negotiated a four-year extension in the deadline for implementing several (the most important) provisions of the YWD (Article 17(1)(b) YWD), namely: Article 8(1)(b) in relation to working time limits for children above the age of 14 with regard to work/training schemes and light work; Article 8(2) in relation to working time limits for children between the ages of 15 and 18; and Article 9(1)(b) and (2) in relation to the prohibition of night work for children between the ages of 15 and 18 . Whilst the European Parliament and the European Commission agreed on the inappropriateness of such an extension, ${ }^{33}$ the Council of the EU bowed to the UK government's concerns and agreed to an 'additional transitional period' - euphemistically called a 'renewable opt-out' by the UK. ${ }^{34}$ Whether it was an 'extension' or a 'renewable opt-out', such an exceptional regime was classified at the time as a uniquely remarkable feature. ${ }^{35}$ The YWD justifies such an exceptional regime in its Preamble by referring to 'particular problems' that the implementation of some provisions posed to the UK's system of protection of young people (Preamble Consideration No. 24). What was, then, clearly in question was, more accurately, the lack of protection for young people in UK labour policy and the consequent special favour granted to the UK. Instead of accommodating any domestic lack of protection and a desire to retain a poorly regulated labour market, though, one could legitimately argue in favour of vigorously strengthening the legal framework applicable to young workers.

\footnotetext{
${ }^{32}$ For a detailed critique of the YWD, see Ferreira, 'Child Labour and EU Law and Policy: A Regional Solution for a Global Issue’, pp. $265 \mathrm{ff}$.

33 Amendment No 28 in Commission of the European Communities, Re-examined proposal for a Council Directive on the protection of young people at work (COM(94) 88 final - SYN 383, 30 March 1994).

${ }^{34}$ Report from the Commission on the Effects of the Transitional Period Granted to the United Kingdom Concerning Certain Provisions of the Council Directive 94/33/EC on the Protection of Young People at Work, Brussels, 20 July 2000, COM(2000) 457 Final, at point 5.2.

35 J. Kenner, EU Employment Law - from Rome to Amsterdam and Beyond (Oxford/Portland, Oregon: Hart, 2003) at 184 .
} 
The Commission proposed the age of 15 as the general minimum age for work but, as the explanatory memorandum to the Commission's proposal indicated, the minimum age in most Member States at the time was already 15 or $16 .{ }^{36}$ The only exception was the UK, where the minimum age was 13 , which may account for the greater resistance demonstrated by the UK to the proposal. At the end of the transposition extension period, the UK argued in favour of a renewal of the transitional period, partially by invoking the 'bogey-monster' type of fear of a shift of working children into the 'black economy'. ${ }^{37}$ The Commission's 2000 report on the transitional period, supported by trade unions and later on by the European Parliament, ${ }^{38}$ concluded, however, that the transitional period should not be extended and that the UK should adhere fully to the Directive, ${ }^{39}$ something eventually not disputed by the UK authorities. ${ }^{40}$

With the UK's transitional period coming to an end, the UK implemented the YWD through The Children (Protection at Work) Regulations 1998. As noted above, the current English and Welsh statutory minimum age of employment enshrined in the Children and Young Persons Act 1933 is 14, which falls short of the age of 15 set out in the YWD. Yet, the minimum school leaving age in England and Wales being 16, the minimum employment age is effectively increased to 16, thus in practice being in compliance with the YWD. Yet, both child workers and employers would benefit from greater clarity and certainty if the statutory norms reflected beyond any doubt the minimum employment age of 16. More worryingly, the minimum age of 13 in relation to light work and the working time limits enshrined in the Children and Young Persons Act 1933 (described in section I), are set at the absolute minimum thresholds allowed by the YWD, which seems to constitute a grudging compliance measure, reflecting very little ambition to offer strong protection in this field. There is, therefore, scope to improve the current English and Welsh legal framework applicable to child work to make it more ambitious and go beyond the bare minimum standards imposed by the EU. In other respects, the EU framework does not seem to have been effective in protecting working children in England and Wales either, as it will now be explored.

\footnotetext{
${ }^{36}$ Commission of the European Communities, Re-examined proposal for a Council Directive on the protection of young people at work.

${ }^{37}$ Report from the Commission on the Effects of the Transitional Period Granted to the United Kingdom Concerning Certain Provisions of the Council Directive 94/33/EC on the Protection of Young People at Work, Brussels, 20 July 2000, COM(2000) 457 Final, at point 6.6.

${ }^{38}$ Resolution on the Commission report on the effects of the transitional period granted to the United Kingdom concerning certain provisions of Council Directive 94/33/EC on the protection of young people at work (COM(2000) 457 - C5-0010/2001/2002(COS)) (OJ No. C 276/36, 1 October 2001).

39 Report from the Commission on the Effects of the Transitional Period Granted to the United Kingdom Concerning Certain Provisions of the Council Directive 94/33/EC on the Protection of Young People at Work, at 10.

${ }^{40}$ Select Committee on European Scrutiny of the UK Parliament, 28th Report, 17 November 2000.
} 


\section{THE MODERN EXPERIENCES OF BRITISH WORKING CHILDREN}

Perhaps due to the influence of the EU and introduction of the YWD in 1994, for a short period of time the debate on child labour and child work more generally increased considerably in the UK in the late 1990s and early 2000s. This activity included a body of literature and data that will be considered here.

Soon after the approval of the YWD, it was argued that '[b]ecause of the general complacency in Britain about child labour, there has been little informed debate and the complexities of the issues are not yet widely understood', and that '[a]ll of the evidence argues against the "commonsense" notions that Britain does not have an issue to deal with in respect to child employment. ${ }^{41}$ Yet, it was estimated in the 2000s that there were between 1 and 2 million children in employment in Britain, which suggested that work was part of a 'normal' childhood experience in Britain, similarly to other wealthy countries. ${ }^{42}$ Moreover, trade unions have reported that over 100,000 children 'play truant' in England and Wales in order to carry out paid work. ${ }^{43}$ Figures from 2010, gathered by the BBC through a Freedom of Information request addressed to all English and Welsh local authorities, indicate that between 2004 and 2009 there was a decline of almost $40 \%$ (from 50,000 to 30,500) in the number of 13-15 yearolds licensed to do part-time work. ${ }^{44}$ Yet, these figures do not reflect the number of children working without a license, which appears to be a pervasive issue, as it will be discussed below. The Labour Force Survey constitutes a more important source of information in this regard, namely in relation to $16-17$ year-olds. $59.4 \%$ of children in this age group were active in the labour market in June-August 1992, as opposed to 57.7\% in June-August in 2000, 45.1\% in June-August 2008 and 33.3\% in June-August 2016. ${ }^{45}$ These figures do indicate a clear decrease in the number of children active in the labour market over the last two decades, but still do not say anything about the issues facing the significant number of children who do work.

\footnotetext{
${ }^{41}$ Hobbs and McKechnie, Child Employment in Britain, at 117 and 122.

42 J. McKechnie and S. Hobbs, 'Work and Education: Are They Compatible for Children and Adolescents?' in P. Mizen, C. Pole, and A. Bolton (eds.), 'Hidden Hands': International Perspectives on Children's Work and Labour (Abingdon/New York: RoutledgeFalmer, 2001), 9-23 at 12; Bourdillon et al., Rights and Wrongs of Children's Work at $48 \mathrm{ff}$.

43 TUC, One in Ten School Kids Play Truant to Work, 2001, <https://www.tuc.org.uk/economic-issues/labourmarket/one-ten-school-kids-play-truant-work>, accessed 1 September 2017.

${ }^{44}$ Abrams, Should children be expected to work.

45 Office for National Statistics, A01: Summary of labour market statistics, 2017, $<$ https://www.ons.gov.uk/employmentandlabourmarket/peopleinwork/employmentandemployeetypes/datasets/s ummaryoflabourmarketstatistics>, accessed 1 September 2017.
} 
Research has highlighted the fact that, despite legislation regulating minimum ages of employment and prohibited forms of child work, many children engage with prohibited forms of employment. ${ }^{46}$ In fact, the majority of child employment in England and Wales is arguably illegal, be it due to the number of hours worked, the age of the child, the type of work, the lack of a work permit, or the time of the day when the work is carried out. ${ }^{47}$ Enforcement of the existing legal framework is thus insufficient (see section V). Besides the range of negative consequences that engaging with such types of unlawful work may entail for the children involved (further explored in this section), not engaging lawfully with work also translates into invisibility in terms of insurance and accident cover, ${ }^{48}$ which leaves children unprotected in case of suffering or causing damage of any nature. Moreover, child work experiences appear to be still considerably gendered, with a clear gender pay gap, and with female children working more in child care, shop work with customer contact, and catering, whilst male children work more in delivery work, shop work stacking shelves and dealing with stocks, agriculture and a range of other forms of manual work..$^{49}$

Reasons offered by children to explain their wish to work often relate to a desire to keep themselves busy, obtain professional experience, gain independence, and have more income available. ${ }^{50}$ The wish to have more income available seems to be closely connected with the wish to use that income to take advantage more fully of the leisure opportunities available to children, particularly sports and cultural activities in the context of an increasingly 'commercialised culture'. ${ }^{51}$ Indeed, the 'colonisation of children's leisure time by commercial organisations, together with the commercialisation of civic responsibility by local authorities, means that the socially inclusive provision of the past has been replaced by the more (socially) exclusive standards of the market'. ${ }^{2}$

\footnotetext{
${ }^{46}$ Hobbs, McKechnie, and Lavalette, Child Labour at 100; Lavalette, Child Employment in the Capitalist Labour Market at 120; Hobbs and McKechnie, Child Employment in Britain at $50 \mathrm{ff}$.

47 TUC, One in Ten School Kids Play Truant to Work; Hobbs, McKechnie, and Lavalette, Child Labour at 13, 141 and 238; Lavalette, Child Employment in the Capitalist Labour Market at 32; Hobbs and McKechnie, Child Employment in Britain at $44 \mathrm{ff}$ and $55 \mathrm{ff}$.

${ }^{48}$ Hobbs and McKechnie, Child Employment in Britain at 8-9; J. McKechnie and S. Hobbs, 'Child Labour: The View from the North', Childhood, 61/1 (1999), 89-100 at 94.

${ }^{49}$ Hobbs, McKechnie, and Lavalette, Child Labour at 100; Lavalette, Child Employment in the Capitalist Labour Market at 120; Hobbs and McKechnie, Child Employment in Britain at $50 \mathrm{ff}$.

${ }^{50}$ McKechnie and Hobbs, 'Child Labour', at 97-8; McKechnie and Hobbs, 'Work and Education' at 14.

${ }^{51}$ H. Ingenhorst, 'Child Labour in the Federal Republic of Germany’, in P. Mizen, C. Pole, and A. Bolton (eds.), 'Hidden Hands', 139-48 at 142; C. Pole, 'Vocabularies, Motives and Meanings - School-Age Workers in Britain: Towards a Synthesis?’ in B. Hungerland and M. Liebel (eds.), Working to Be Someone: Child Focused Research and Practice with Working Children (London/Philadelphia: Jessica Kingsley Publishers, 2007), 151-60 at 156.

${ }^{52}$ P. Mizen, C. Pole, and A. Bolton, 'Why Be a School Age Worker?’ in P. Mizen, C. Pole, and A. Bolton (eds.), 'Hidden Hands', 37-54 at 53.
} 
Children in the UK tend to work in the service sectors, retail, hotel and catering industry, and personal services, as well as baby-sitting, car-washing and other self-employed tasks. ${ }^{53}$ The type of work carried out by children in the UK is generally unskilled, poorly paid, 'around the edges of the formal labour market', often involving simple and repetitive tasks in high volume, and only rarely allows children to acquire a particular recognisable skill or be in any way creative. ${ }^{54}$ Lavalette also points out that 'children now occupy a distinct position in the labour market, being employed in small undercapitalised sectors of the economy or in jobs that are uniformly regarded as the domain of child workers', although there is also evidence of children carrying out types of jobs that adults also carry out as full time jobs. ${ }^{55}$ As many of the employers in question are small employers, often family businesses, the use of part-time and casual labour is extensive and 'children can offer a ready source of cheap hours and flexible labour, one that is available at short notice, tolerates irregular hours and has low expectations of work. ${ }^{56}$ It has also been found that, even if gaining 'soft skills' such as communication and interpersonal skills, younger children (14-15 years old) are less likely than older children (1617 years old) to receive any sort of training, have contact with customers or deal with money, thus diminishing the relevance of that work experience for future employment. ${ }^{57}$

Qvortrup interestingly asserts that 'the recognition of children as manual workers in the midst of a society marked by abstract and symbolic work may be the final confirmation of the way we regard children as immature. Manual labour is nowadays emblematic of discarded and primitive stages of social development, and therefore suitable to the image of children as developmentally incompetent and incapable. ${ }^{58}$ Although one may rightly query this vision of manual work as somehow 'primitive’ and 'undeveloped', Qvortrup justifiably makes a link between the generally unskilled and manual work children do and societal (or at least employers') likely perceptions of children as unsuitable for more intellectually demanding work. Lavalette also highlights that children's perceived social position devalues their work and 'the cheapness of children's jobs reinforces their distinctive character and position within

53 V. Morrow, 'Responsible Children? Aspects of Children's Work and Employment Outside School in Contemporary UK', in B. Mayall (ed.), Children's Childhoods: Observed and Experienced (London/Washington, D.C.: Falmer Press, 1994), 128-43 at 131.

${ }^{54}$ Mizen, Pole, and Bolton, 'Why Be a School Age Worker?’ at 39; Lavalette, Child Employment in the Capitalist Labour Market at 25; Hobbs and McKechnie, Child Employment in Britain at $47 \mathrm{ff}$; Pole, 'Vocabularies, Motives and Meanings'.

${ }^{55}$ Lavalette, Child Employment in the Capitalist Labour Market at 3 and 24.

${ }^{56}$ Mizen, Pole, and Bolton, 'Why Be a School Age Worker?' at 40.

57 J. McKechnie and S. Hobbs, 'Children's Work as Preparation for Adulthood: A British Perspective', in B. Hungerland and M. Liebel (eds.), Working to Be Someone, 99-107.

58 J. Qvortrup, 'School-Work, Paid Work and the Changing Obligations of Childhood', in P. Mizen, C. Pole, and A. Bolton (eds.), 'Hidden Hands', 91-107 at 104. 
the labour market', which has become one of marginalisation. ${ }^{59}$ Leonard reinforces this by pointing to the way adults dismiss the skills associated with child work, particularly in relation to those tasks commonly carried out by children. ${ }^{60}$ This may be seen both as an unfair perception of children's true competences, and as the confirmation that children may benefit more from education than work.

In terms of effects of work on children, one could refer to many dramatic cases of children suffering horrific accidents and even dying whilst working. ${ }^{61}$ A 2013 case, for example, saw a 16-year-old apprentice die in a Greater Manchester factory due to an injury to his head. ${ }^{62}$ Leaving the most dramatic cases aside, however, there are still plenty of worrying consequences one needs to highlight.

A clear link has been established between work carried out by children and educational attainment. In a survey carried out by TUC in England and Wales, 29\% of the children reported often or sometimes feeling too tired to do homework or school work. ${ }^{63}$ Exact causal links depend on the particular study, region or data used, but in Britain one may point out an average of 25\% more passes in O levels and GCSE results for those children not working, and a negative effect of work on A-level results. ${ }^{64}$ It has also become clear that working a small number of hours/week seems not to have any negative impact on academic performance and may even improve exam results, but when working more than five hours/week the negative effect on the academic performance and school attendance increases with the increase of the number of hours worked. ${ }^{65}$ So, whilst education and employment are not necessarily incompatible, limits to the number of hours worked and the nature of the activity are clearly desirable to avoid negative effects on the educational progress of the children wishing to work.

Other effects worth noting include $20-30 \%$ of working children in Britain sustaining some form of accidental injury, ${ }^{66}$ and at any rate suffering a higher rate of accidents than adult workers, particularly in the context of delivery work. ${ }^{67}$ Lavalette has rightly asserted that

\footnotetext{
${ }^{59}$ Lavalette, Child Employment in the Capitalist Labour Market at 9 and 32.

${ }^{60}$ M. Leonard, 'Working on Your Doorstep: Child Newspaper Deliverers in Belfast', Childhood, 9/2 (2002), 190204 at 201.

${ }^{61}$ Hobbs and McKechnie, Child Employment in Britain at 22.

62 BBC, 'Bury’s Huntley Mount Engineering Accused over Apprentice Death', <http://www.bbc.co.uk/news/ukengland-manchester-29672959>, accessed 1 September 2017.

63 TUC, One in Ten School Kids Play Truant to Work.

${ }^{64}$ McKechnie and Hobbs, 'Work and Education' at 16-18.

${ }^{65}$ McKechnie and Hobbs, 'Child Labour', at 96; Hobbs and McKechnie, Child Employment in Britain, at 92 ff; McKechnie and Hobbs, 'Work and Education' at 16-18.

${ }^{66}$ Hobbs, McKechnie, and Lavalette, Child Labour, at 1.

${ }^{67}$ Hobbs and McKechnie, Child Employment in Britain, at $58 \mathrm{ff}$.
} 
children's jobs in Britain are far from 'harmless and healthy' ${ }^{68}$ Family agriculture businesses, in particular, are prone to competition and globalisation, which often leads to the use of the work of all family members - including children - for long and intense periods of time. In this context, 'children remain a vulnerable and exploited source of labour' in farms, which have been found to be very unsafe places for children. ${ }^{69}$

Although not of direct concern to the children themselves, it is worth also mentioning the risk of child work having a detrimental effect on the wages of other disadvantaged employees, for example, part-time female workers. ${ }^{70}$ Children themselves also generally receive very low pay, ${ }^{71}$ which is made easy by the lack of a minimum wage for under-16s, and lower rates of pay for under-18 year-olds. ${ }^{72}$ Although often masqueraded as a measure to promote youth employment, this has been rightly critiqued by trade unions as exploitative. ${ }^{73}$

Furthermore, although counter-intuitive perhaps, one should point out that higher poverty indicators are inversely related to the proportion of working children, ${ }^{74}$ and children with only one parent and with families receiving Income Support are less likely to have a parttime job than other children. ${ }^{75}$ Child work experiences are thus more closely related to middle class families, linking child work in developed countries to a 'bourgeois' ideology. ${ }^{76}$ Children from more disadvantaged socio-economic backgrounds seem, instead, to end up working outside formal employment relationships, for longer hours, and earning less per hour. ${ }^{77}$

Finally, it is also pertinent to refer to the existence of child soldiers in the UK. Although in popular discourses child soldiers are generally linked to developing countries and ravaging civil wars, the UK recruits into its armed forces children from the age of 16 onwards and this

\footnotetext{
${ }^{68}$ Lavalette, Child Employment in the Capitalist Labour Market, at 119.

${ }^{69}$ Hobbs, McKechnie, and Lavalette, Child Labour, at 5-7; D. L. Parker, A. G. Fassa, and T. J. Scanton, 'Understanding the Health Effects of Child Labour', in A. G. Fassa, D. L. Parker, and T. J. Scanton (eds.), Child Labour: A Public Health Perspective (Oxford: Oxford University Press, 2010), 103-17 at 112.

${ }^{70}$ Lavalette, Child Employment in the Capitalist Labour Market, at 119-20.

${ }^{71}$ McKechnie and Hobbs, 'Child Labour', at 93; TUC, One in Ten School Kids Play Truant to Work, at 154; Pole, 'Vocabularies, Motives and Meanings'.

72 National Minimum Wage and National Living Wage rates, <https://www.gov.uk/national-minimum-wagerates>, accessed 1 September 2017. For a lengthier discussion of the discrimination children suffer in the world of labour, particularly in relation to pay, see Ferreira, 'Working Children in Europe: A Socio-Legal Approach to the Regulation of Child Work'.

73 M. Carley, 'Minimum Wage Frozen for Young Workers' (24 May 2012) <http://www.eurofound.europa.eu/observatories/eurwork/articles/working-conditions/minimum-wage-frozenfor-young-workers>, accessed 1 September 2017.

${ }^{74}$ McKechnie and Hobbs, 'Work and Education', at 21.

75 S. Middleton and J. Loumidis, 'Young People, Poverty and Part-Time Work', in Phillip Mizen, Christopher Pole, and Angela Bolton (eds.), 'Hidden hands', 24-36 at 28.

${ }^{76}$ Lavalette, Child Employment in the Capitalist Labour Market, at 219.

77 S. Middleton and J. Loumidis, 'Young People, Poverty and Part-Time Work', in P. Mizen, C. Pole, and A. Bolton (eds.), 'Hidden Hands', 24-36 at 31.
} 
makes it stand out as the only European country to do so. ${ }^{78}$ Although subject to a special legal framework, ${ }^{79}$ children being recruited and working for the UK armed forces are protected by employment safeguards, hence the appropriateness of discussing them in the context of this analysis. Child soldiering is considered one of the worst forms of child labour according to Article 3 ILO C182, and is prohibited until the age of 15 by Article 38(3) CRC. In addition, 2000 saw the adoption of the Optional Protocol to the Convention on the Rights of the Child on the involvement of children in armed conflict, ${ }^{80}$ which encourages States Parties not to allow children to take a direct part in hostilities (Article 1), not to compulsory recruit children (Article 2), and to raise the minimum age for the voluntary recruitment beyond 15 (Article 3). The UK has signed and ratified this Protocol, and the compliance of the current practices in the UK with it has been questioned, particularly in relation to the full and informed consent required from children. ${ }^{81}$ More generally, as I have argued elsewhere, even if child soldiering may be characterised by a degree of child volition and agency, it is still largely a socio-economic and political product related to disadvantages and depravation suffered, for example, in terms of housing and education. ${ }^{82}$ Societies should thus combat the circumstances that make military recruitment at such a young age seem like a better choice than education or training.

Several international bodies, NGOs and UK public bodies have argued along the same lines for many years, and put pressure on the Government to raise to 18 the minimum age of consent for voluntary recruitment into the armed forces in the UK. ${ }^{83}$ The case for this is extremely strong, and based on a broad range of reasons, many of which are close to the issues discussed above in relation to non-military related forms of work. These reasons include: 1) the biological and physiological stage of development of teenagers (which tends to favour

\footnotetext{
${ }^{78}$ Child Soldiers International, Louder than words: An agenda for action to end state use of child soldiers, London, 2012, < <https://www.child-soldiers.org/Handlers/Download.ashx?IDMF=da92581e-7130-40e6-bf3aa86b944f17dd>, accessed 1 September 2017.
79 British Army, Terms
and
Conditions
of
2015,

Service, <http://www.army.mod.uk/documents/general/TermsofService.pdf>, accessed 1 September 2017.

${ }^{80}$ Optional Protocol to the Convention on the Rights of the Child on the involvement of children in armed conflict, adopted and opened for signature, ratification and accession by General Assembly resolution A/RES/54/263 of 25 May 2000 and entry into force 12 February 2002.

${ }^{81}$ According to David McCoy, director of Medcat, quoted in Amelia Hill, 'Under-18s in army "face greater injury, death and mental health risks”', The Guardian, 18 October 2016, <https://www.theguardian.com/uknews/2016/oct/18/under-18s-in-army-face-greater-injury-death-and-mental-health-risks>, accessed 1 September 2017.

${ }^{82}$ Ferreira, 'Working Children in Europe: A Socio-Legal Approach to the Regulation of Child Work', 72-3.

${ }^{83}$ Child Soldiers International and ForcesWatch, One Step Forward: The case for ending recruitment of minors by the British armed forces, 2013, $<$ https://www.forceswatch.net/sites/default/files/One_Step_Forward_April_2013.pdf >, accessed 1 September 2017; Medact, The Recruitment of Children by the UK Armed Forces - a critique from health professionals, 2016, $<$ https://www.medact.org/wp-content/uploads/2016/10/medact_childrecruitment_17-oct_WEB.pdf> accessed 1 September 2017.
} 
immediate social rewards and risk-taking behaviours, whilst also being characterised by a 'critical time of vulnerability'); 2) the lack of genuinely voluntary and informed consent from 16-18 year olds (especially in the light of the focus of recruitment efforts in socio-economically disadvantaged areas, and the misleading nature of the 'glamorous' portrayal of military life); 3) the long-term physical and mental health problems of soldiers recruited before becoming adults (including in terms of fatality and injury rates, incidence of post-traumatic stress disorder, alcohol misuse, self-harm and suicide); and 4) the poor educational opportunities offered to young military recruits. ${ }^{84}$ Numerous individuals recruited into the UK military forces whilst still children have come forward to highlight these very real negative consequences of allowing children to engage with military life, as well as the Army Cadet Forces' grooming practices for children as young as $12 .{ }^{85}$ This process of militarisation of children is set to expand, with plans to take a watered down version of cadet training to state schools, especially schools in less affluent areas. ${ }^{86}$ This plan, however, has been rightly criticised for being inappropriate in educational settings, normalising the use of guns, and acting as a recruitment tool for the Armed Forces. ${ }^{87}$

Despite the seriousness of all the child work related issues highlighted here, there is barely any awareness of these matters in public and political debates. This may be due to constituents not perceiving these matters as worrying, thus not putting pressure on MPs to tackle such matters; or to politicians thinking that suggesting a stronger stance in this field would not bring them any electoral advantage; or an overall cultural mind-set and labour market ethos that does not motivate the media and policy-makers to enquire further into these matters; or a combination of these and other reasons that require further exploration. Whatever those reasons may be, even in contexts where child workers should be a key element of the analysis, they tend to be side-lined or erased from the current debates. Let us consider the 'Human Rights and Business 2017: Promoting responsibility and ensuring accountability' report, produced by the House of Lords and House of Commons Joint Committee on Human

\footnotetext{
${ }^{84}$ Medact, The Recruitment of Children by the UK Armed Forces - a critique from health professionals; Child Soldiers International, Mind the Gap: Education for minors in the British armed forces, July 2012, $<$ https://www.child-soldiers.org/Handlers/Download.ashx?IDMF=3e7778d0-ebaa-402b-9dcc-0d3f1253428d>, accessed 1 September 2017.

${ }^{85}$ Hill, 'Under-18s in army "face greater injury, death and mental health risks”'; Army Cadet Force, 'About the Army Cadet Force', <https://armycadets.com/about-us/>, accessed 1 September 2017.

${ }^{86}$ Nazia Parveen, 'A night on the frontline with Michael Fallon's school cadet corps', 7 October 2016, The Guardian, <https://www.theguardian.com/uk-news/2016/oct/07/michael-fallon-defence-secretary-army-cadetunits-expansion-programme-wallasey>, accessed 1 September 2017.

${ }^{87}$ Parveen, 'A night on the frontline with Michael Fallon's school cadet corps'; Hill, 'Under-18s in army "face greater injury, death and mental health risks”.
} 
Rights. ${ }^{88}$ Although the report does contain references to child labour as a serious human rights violation and alludes to UNICEF's concern that children are particularly vulnerable to abuse by companies, child work is only acknowledged as taking place abroad (in the textile industry in Turkey, in the mining industry in the Democratic Republic of Congo, and in the tobacco industry in Malawi and Indonesia). Furthermore, the Committee refers to the UNCRC 2016 recommendation that the UK Government should 'integrate an explicit focus on children's rights, including the requirement for businesses to undertake child-rights due diligence, in the revised version of its first National Action Plan'; yet, there is not explicit link between this recommendation and children as workers, leaving readers to interpret this recommendation as relating exclusively to children as premises occupiers, consumers and members of the public.

Another recent example of the side-lining of child work issues in the UK can be seen in the 2017 'Taylor review of modern working practices' ${ }^{89}$ The review understandably had a limited remit, and focused on: security, pay and rights, progression and training; the balance of rights and responsibilities; representation; opportunities for under-represented groups; and new business models. Child work was not one of the particular issues to be analysed in this review, but it is still striking that in a 111-page report there was no explicit reference to children in the labour market, not even in connection to one of the themes within the remit of the review.

There is thus a palpable reluctance to look at child work practices in our own surroundings, conceiving it only as a problem that occurs abroad and that does not require any scrutiny of domestic practices. That lack of scrutiny is, unfortunately, compounded and supported by a lack of institutional enforcement of the current legal framework.

\section{LEGAL (UN)ENFORCEMENT}

Unlike in many other European countries, in the UK regulation of child work is mainly enforced by local authorities, as opposed to a centralised labour inspectorate, although the Health and Safety Inspectorate also plays a role in relation to child workers. ${ }^{90}$ The shortcomings of the UK labour standards enforcement have come under fire for years, which - allied with

\footnotetext{
${ }^{88}$ House of Lords and House of Commons Joint Committee on Human Rights, Human Rights and Business 2017: Promoting Responsibility and Ensuring Accountability - Sixth Report of Session 2016-17, HL Paper 153 / HC 443, 2017, <https://publications.parliament.uk/pa/jt201617/jtselect/jtrights/443/443.pdf>, accessed 1 September 2017.

89 Matthew Taylor et al., Good Work: The Taylor Review of Modern Working Practices, 2017, <https://www.gov.uk/government/uploads/system/uploads/attachment_data/file/627671/good-work-taylorreview-modern-working-practices-rg.pdf>, accessed 1 September 2017.

90 Health and Safety Executive, Young People at Work, <http://www.hse.gov.uk/youngpeople/index.htm>, accessed 1 September 2017.
} 
mediatic reports of instances of worker exploitation in the sports retail sector $-{ }^{91}$ contributed to the joint Department for Business, Innovation and Skills / Home Office public consultation on 'Tackling Exploitation in the Labour Market'. ${ }^{92}$ Neither the consultation document nor the Government's response, ${ }^{93}$ however, made any reference to child work - children were thus again invisible in the discussions carried out. This consultation led to the Immigration Act 2016, which introduced a considerable number of significant changes to the previous labour standards enforcement system, including: the creation of the role of Director of Labour Market Enforcement, responsible for setting strategic priorities for the labour market enforcement bodies; the creation of an intelligence hub to support this new position of Director, enhancing the scope for data sharing between the Director, the Intelligence Hub, the labour market enforcement bodies, and other relevant bodies; the creation of a new labour market undertaking and enforcement order regime, including criminal and custodial offences; and, perhaps most important, the reform of the Gangmasters Licensing Authority into the Gangmasters and Labour Abuse Authority, a body with broader and stronger powers to address instances of labour exploitation. ${ }^{94}$

The task of enforcing labour standards in the UK remains dispersed, though, as there are still three central bodies involved: the Employment Agencies Standard Inspectorate, Her Majesty’s Revenue and Custom's National Minimum Wage team and the (now) Gangmasters and Labour Abuse Authority. Significantly, the work carried out by the Gangmasters and Labour Abuse Authority seems to hardly impinge on any child-related violations of labour standards. A survey of the Authority's website indicates that 'children' only come up in the context of modern slavery, forced labour and trafficking, ${ }^{95}$ thus ignoring all the other contexts

\footnotetext{
${ }^{91}$ Simon Goodley, 'Government Names New Chief to Lead Crackdown on Worker Exploitation', The Guardian, 2017, <https://www.theguardian.com/money/2017/jan/05/government-names-new-chief-to-lead-crackdown-onworker-exploitation>, accessed 1 September 2017.

${ }^{92}$ Innovation and Skills / Home Office Department for Business, Tackling Exploitation in the Labour Market Consultation, <https://www.gov.uk/government/uploads/system/uploads/attachment_data/file/471048/BIS-15549-tackling-exploitation-in-the-labour-market.pdf>, accessed 1 September 2017.

${ }^{93}$ Innovation and Skills / Home Office Department for Business, Tackling Exploitation in the Labour Market Government Response, $<$ https://www.gov.uk/government/uploads/system/uploads/attachment_data/file/491260/BIS-16-11-governmentresponse-to-tackling-exploitation-in-the-labour-market.pdf >, accessed 1 September 2017, ILPA - Immigration Law Practitioners' Association, Information Sheet: Immigration Act 2016: The Labour Market, $<$ http://www.ilpa.org.uk/resources.php/32427/information-sheet-immigration-act-2016-2-labour-marketenforcement-updated-01-november-2016>, accessed 1 September 2017.

${ }^{94}$ ARC, 'New Role of Director of Labour Market Enforcement', <http://www.arc-org.net/new-role-of-directorof-labour-market-enforcement/>, accessed 1 September 2017.

${ }^{95}$ Gangmasters and Labour Abuse Authority, 'Modern Slavery', <http://www.gla.gov.uk/who-we-are/modernslavery/>, accessed 1 September 2017; Gangmasters and Labour Abuse Authority, '13 Arrested in Peterborough in Connection with Exploitation', 21 April 2015, <http://www.gla.gov.uk/whats-new/press-releasearchive/21415-13-arrested-in-peterborough-in-connection-with-exploitation/>, accessed 1 September 2017;
} 
in which children engage with the labour market in potentially unsafe and detrimental ways for them. This is a reflection of the worrying increasing policy-making link between labour standards enforcement and (perceived) immigration-related phenomena, as it will be further discussed below.

The appointment of the first Director of Labour Market Enforcement - Sir David Metcalf - was reported as having as a key priority leading on the enforcement of the National Living Wage. ${ }^{96}$ Unison rightly called on Sir David Metcalf to fight against the widespread illegal practices that affect apprentices' wages (with nearly a quarter of 16-18 year old apprentices being on the wrong pay levels), and highlighted that 'apprentices aged 16 to 18 were hit hardest by minimum wage non-compliance'. ${ }^{97}$ Although this focus on National Living Wage compliance could benefit child workers, it seemingly downplays a range of violations of other serious labour market standards related to child workers. And, as Shakira Martin (the National Union of Students vice-president for Further Education), stated, 'the creation of a director of labour market enforcement [can be welcomed] as an opportunity to protect the employment rights of students, young people and apprentices', but that opportunity does not seem to have been acted upon or benefitted child workers in any way. Moreover, the new regime of Labour Market Enforcement Undertakings and Orders was hailed as an important element of this reform, ${ }^{98}$ but again contains nothing of particular use for children in the labour market. $^{99}$

More worryingly, this reform to the labour standards enforcement setup in the UK revolved around immigration control issues, as opposed to labour standard priorities. This was painfully obvious owing to the fact that this whole reform was linked to amendments to immigration law and modern slavery debates and policy-making. ${ }^{100}$ So, as Balch rightly points

Gangmasters and Labour Abuse Authority, 'GLA Helps Uncover “Trafficking” Operation', 16 July 2013, <http://www.gla.gov.uk/whats-new/press-release-archive/16713-gla-helps-uncover-trafficking-operation/>, accessed 1 September 2017.

${ }^{96}$ Christopher Williams, 'New Labour Market Tsar Sir David Metcalf to Lead Crackdown on National Living Wage Abuse’, The Telegraph, 2017 <http://www.telegraph.co.uk/business/2017/01/05/new-labour-market-tsarsir-david-metcalf-lead-crackdown-national/>, accessed 1 September 2017.

97 Alix Robertson, 'Unison: New Labour Market Tsar Must Protect Underpaid Apprentices', <http://feweek.co.uk/2017/01/14/unison-new-labour-market-tsar-must-protect-underpaid-apprentices/>, accessed 1 September 2017.

${ }^{98}$ Lorna Scully, 'New Measures to Tackle Exploitation in the Labour Market - What You Need to Know', $<$ http://www.jordanpublishing.co.uk/practice-areas/employment/news_and_comment/new-measures-to-tackleexploitation-in-the-labour-market-what-you-need-to-know\#.WW82wFGQyUk>, accessed 1 September 2017.

99 Energy \& Industrial Strategy Home Office / Department for Business, Code of Practice on Labour Market Enforcement Undertakings and Orders, 2016, <https://www.gov.uk/government/publications/labour-marketenforcement-undertakings-and-orders-code-of-practice>, accessed 1 September 2017.

${ }^{100}$ Alex Balch, 'New Strategy to Tackle Labour Exploitation Complicated by Immigration and Modern Slavery Focus', <http://www.ier.org.uk/blog/new-strategy-tackle-labour-exploitation-complicated-immigration-andmodern-slavery-focus>, accessed 1 September 2017. 
out, rather than fully addressing the doubts that have existed for so long about the 'integrity and effectiveness of UK labour market governance in preventing issues such as exploitation or forced labour', this reform has had the pernicious effects of unjustifiably formalising the 'fusion of enforcement of labour standards with enforcement of immigration controls' and sidestepping the 'structural causes of exploitation' ${ }^{101}$ This may lead to concentrating the work of the new Gangmasters and Labour Abuse Authority on just a few high-profile operations in high-risk sectors, as opposed to a more wide-spread intervention across all labour and economic sectors. ${ }^{102}$ These developments thus do not offer anything to child workers in the UK, and one needs to essentially continue to rely on (the very limited) local authorities' enforcement of labour standards.

Considering the limited scope for action and budgets of local authorities, one justifiably wonders whether their resources and structure are sufficient and appropriate for such a task. ${ }^{103}$ Indeed, since the 1990s it has been pointed out that, bearing in mind past experience of ineffective application of the law, local authorities should have been offered additional resources alongside the adaptation of UK law to the YWD. ${ }^{104}$ Crucially, in the light of the small amounts of fines and insufficient resources dedicated to registration, inspection and prosecution in the UK, 'the risks and costs of flouting child labour laws for employers are negligible. ${ }^{105}$ The fact that so many children work unlawfully (as seen in section IV) seems to be evidence of the inadequacy of the enforcement (not) carried out by local authorities. It is also a reflection of lack of awareness of existing regulations by all actors involved and of lack of prioritisation of this area by local authorities. ${ }^{106}$ More worryingly, the fact '[t]hat the legislation is not applied means that the possibility of exploiting those it is intended to protect is more likely.' 107 This situation can only have been made worse by the cuts to local government carried out by the Coalition Government in 2015-2016. Either local authorities are effectively equipped to deal with the enforcement of child work regulations, or the enforcement of these regulations needs to be radically overhauled. This could materialise by perhaps shifting

\footnotetext{
101 Ibid.

102 Ibid.

103 Hobbs, McKechnie, and Lavalette, Child Labour, at 238.

104 D. Cornwell, K. Graham, and S. Hobbs, 'Honoured in the Breach: Child Employment Law in Britain', in M. Lavalette (ed.), A Thing of the Past: Child Labour in Britain in the Nineteenth and Twentieth Centuries (Liverpool: Liverpool University Press, 1999), 216-30 at 229.

${ }^{105}$ G. Rikowski and M. Neary, 'Working Schoolchildren in Britain Today’, Capital and Class, 21/3 (1997), 2535 at 26.

${ }^{106}$ B. Whitney, 'Unenforced or Unenforceable? A View from the Professions', in M. Lavalette (ed.), A Thing of the Past, $15-43$ at 233-4.

${ }^{107}$ Hobbs and McKechnie, Child Employment in Britain, at 119.
} 
the relevant competences and legal powers to a centralised legal enforcement authority - most likely the Gangmasters and Labour Abuse Authority - provided this body would be endowed with the necessary resources and legal framework, which is not likely to happen in the current climate and considering the recent reform analysed above.

One should thus recall the obligations that Article $32 \mathrm{CRC}$ and its interpretation by the UNCRC impose on its Member States (thus including the UK) in relation to the enforcement of child labour regulations. This includes involving NGOs, private sector organisations and children themselves in monitoring and enforcing these regulations, and endowing labour inspectorate authorities with the necessary resources to monitor the enforcement of these norms. ${ }^{108}$ The UNCRC has reiterated this message by insisting that states 'must have functioning labour inspection and enforcement systems and capacities in place', and strengthen 'regulatory agencies responsible for the oversight of standards relevant to children's rights such as $(\ldots)$ labour $(\ldots)$ so that they have sufficient powers and resources to monitor and to investigate complaints and to provide and enforce remedies for abuses of children's rights'. ${ }^{109}$ Yet, UK authorities seem to remain oblivious to these international obligations and corresponding authoritative interpretations, perhaps due to a good degree of resistance against external interference from international organisations.

Moreover, local authorities can be more effective in promoting awareness of child work issues and the work permit system through campaigns, ${ }^{110}$ and use spot-checks as a deterrent. ${ }^{111}$ Yet another avenue of reform relates to the possibility of building in incentives into the permit system to encourage children to acquire permits, for example, by framing permits in empowering (rather than prohibitive) terms. ${ }^{112} \mathrm{~A}$ more concerted nation-wide strategy focussing more on licencing employers than on giving work permits to child workers could also produce better results. ${ }^{113}$

One should also consider strategies that create space for engagement and intervention of actors other than public authorities. Schools can be seen as ideal platforms to educate children about their employment and labour rights, and the health and safety requirements that children need to respect to avoid harm to their well-being and development. Despite their

\footnotetext{
108 L. Swepston, A Commentary on the United Nations Convention on the Rights of the Child: Article 32 Protection from Economic Exploitation (Leiden: Brill, 2012) at 26-7.

${ }^{109}$ Committee on the Rights of the Child, General Comment No. 16 (2013) on State Obligations Regarding the Impact of Business on Children's Rights, at para. 56 and 61.

${ }^{110}$ Hobbs and McKechnie, Child Employment in Britain at $23 \mathrm{ff}$.

111 TUC, One in Ten School Kids Play Truant to Work.

112 M. Leonard, 'Children’s Views on Children's Right to Work', Childhood, 11/1 (2004), 45-61 at 48.

${ }^{113}$ Whitney, 'Unenforced or Unenforceable?’, at 242-3.
} 
increasingly restricted role in the UK, trade unions can also play an important role in identifying and reporting child labour, supporting child workers' complaints, and using their negotiation and collective bargaining powers to avoid child labour. ${ }^{114}$ Finally, one should not forget children's rights to participation in decision-making processes affecting their rights and interests, as enshrined in Article 12 CRC. In this respect, the UNCRC rightly alerts states to the fact that '[g]overnmental bodies, such as education and labour inspectorates, concerned with regulating and monitoring the activities and operations of business enterprises should ensure that they take into account the views of affected children', ${ }^{115}$ including child work regulations and practices. Child work regulations should thus be enforced and monitored in creative and holistic ways, which deserve exploration beyond the scope of this article. Whatever we do, we should not exempt public authorities of their responsibility in this field or succumb to the 'budget cuts inevitability' mantra.

\section{CONCLUSION: TIME TO WAKE UP FROM INERTIA?}

Now, as in the 1990s, there is 'enough evidence to demonstrate that British child workers are at considerable risk - of injury, wage exploitation and unsafe and inappropriate work - within a context of inadequate legal protection and law enforcement and patchy local authority monitoring. ${ }^{116}$ This obviously requires a complex, multifaceted reaction from authorities and society alike. ${ }^{117}$ This is all the more the case following the increase in child poverty in the UK over the last decade, owing not only to the 2008 economic crisis, but also UK policy measures relating to cuts to the real value and coverage of child benefits and tax credits for families with children, as well as the total benefits a household can receive. ${ }^{118}$ Although some aspects of the benefit cap measures have been successfully challenged in courts, ${ }^{119}$ the overall austerity policy trend remains, with the highly likely impact of children becoming involved with the labour market in unregulated and exploitative ways.

\footnotetext{
${ }^{114}$ Leonard, 'Children's Views on Children's Right to Work', at 55; G. Myrstad, 'What Can Trade Unions Do to Combat Child Labour?’ Childhood, 6/1 (1999), 75-88.

${ }^{115}$ Committee on the Rights of the Child, General Comment No. 16 (2013) on State Obligations Regarding the Impact of Business on Children's Rights, at par. 21.

${ }^{116}$ Rikowski and Neary, ‘Working Schoolchildren in Britain Today’, at 32.

${ }^{117}$ For greater detail on what this reaction should entail, see N. Ferreira, 'Working Children in Europe'.

118 UNICEF Office of Research, Children of the Recession: The Impact of the Economic Crisis on Child WellBeing in Rich Countries - Innocenti Report Card 12 (Florence: UNICEF Office of Research, 2014).

119 See, in relation to carers, Hurley \& Ors v Secretary of State for Work and Pensions [2015] EWHC 3382 (Admin), [2016] PTSR 636, [2015] WLR(D) 485; and more recently, in relation to lone parents with children under the age of two, DA \& Ors, $R$ (On the Application Of) v Secretary of State for Work and Pensions [2017] WLR(D) 409, [2017] EWHC 1446 (Admin), [2017] WLR(D) 449.
} 
Monitoring what happens in the field is crucial with regard to child labour, as Muižnieks has highlighted, so this constitutes a first priority in this policy area. ${ }^{120}$ Any move towards selfregulation and autonomous supervision by employers should be resisted (for example in relation to supervision of vocational training), no matter how economically or ideologically appealing these may be to some. The era of self-regulation has already borne its bitter fruits, mainly in the field of financial services, so robust, public-led enforcement remains essential. ${ }^{121}$

As most studies and data available regarding English and Welsh working children relate to the 1990s and early 2000s, the existing empirical data is insufficient and outdated. Consequently, a second priority is to carry out extensive longitudinal empirical research on children's work experiences in England and Wales. Once that data is gathered and analysed, policy-makers will be in a much better position to strengthen the current legal framework and its enforcement in an effective and appropriate manner.

Finally, with an impending exit of the UK from the EU, and depending on the exact terms of the agreement to be signed with the EU, the UK may no longer need to comply with the YWD in a few years' time. The combination of policy-makers' euro-sceptic leanings with a 'dualist model' legal mind-set in relation to the implementation of international obligations represents a great danger to child workers in the UK. Yet, in the light of the UK's socioeconomic development, an effort must be made to uphold and go beyond European and international standards in this field, namely through sharing of best practices and using the Council of Europe, EU, ILO and UN institutional frameworks. Opportunity must also be created to reform English and Welsh law to bring together the relevant rules under a single, clear and concise statute, to offer legal certainty and an up-to-date picture of the applicable legal framework to all stakeholders. Whatever we do, complacency is not an option.

\footnotetext{
${ }^{120}$ Muižnieks, 'Child Labour in Europe: A Persisting Challenge’.

${ }^{121}$ On hard/soft law instruments for labour standards enforcement, see special issue 'Mapping the Hard Law/Soft Law Terrain: Labor Rights and Environmental Protection’, Theoretical Inquiries in Law, Volume 12, Issue 2 (July 2011).
} 